\title{
TTR
}

Traduction, terminologie, re?daction

\section{The Phonetic Representation of Spoken Language in Modern Hebrew Literature}

\section{Rina Ben-Shahar}

Volume 8, numéro 2, 2e semestre 1995

Technolectes et dictionnaires

URI : https://id.erudit.org/iderudit/037226ar

DOI : https://doi.org/10.7202/037226ar

Aller au sommaire du numéro

\section{Éditeur(s)}

Association canadienne de traductologie

ISSN

0835-8443 (imprimé)

1708-2188 (numérique)

Découvrir la revue

\section{Citer cet article}

Ben-Shahar, R. (1995). The Phonetic Representation of Spoken Language in Modern Hebrew Literature. TTR, 8(2), 249-273. https://doi.org/10.7202/037226ar

\section{Résumé de l'article}

La représentation phonétique de la langue parlée dans la littérature hébraïque moderne - La langue écrite transmet de façon normative le modèle graphique complet d'un mot sans dévier des règles orthographiques d'une langue donnée. Cependant, lorsque les signes graphiques visent à représenter la langue parlée utilisée dans une conversation naturelle, le problème de l'imitation phonétique de la langue parlée retranscrite dans un texte se pose. Le présent article traite de la position de la langue parlée dans les fictions narratives et dans le théâtre en hébreu, ainsi que ses modes de représentation à partir de 1948 dans des oeuvres en hébreu, y compris des oeuvres traduites de l'anglais. Cette question est abordée en faisant fond sur d'autres questions plus vastes : la situation particulière de l'hébreu, qui a longtemps été exclusivement une langue écrite dénuée des fonctions variées d'une langue parlée; les normes stylistiques-linguistiques de la littérature hébraïque depuis 1948 et leurs transformations; la conscience que les écrivains et les traducteurs hébreux avaient des principes de la langue parlée en général et de ceux du vernaculaire hébreu en particulier; les différences dans la formation des dialogues entre les divers sous-systèmes littéraires : le théâtre par rapport à la fiction narrative et la littérature en langue d'origine par rapport à la littérature traduite, y compris les intersections des deux. Ces questions sont abordées sous un angle tant synchronique que diachronique.
Tous droits réservés @ C TTR: traduction, terminologie, rédaction — Les auteurs, 1995
Ce document est protégé par la loi sur le droit d'auteur. L'utilisation des services d'Érudit (y compris la reproduction) est assujettie à sa politique d'utilisation que vous pouvez consulter en ligne.

https://apropos.erudit.org/fr/usagers/politique-dutilisation/ 


\section{The Phonetic Representation of Spoken Language in Modern Hebrew Literature}

\section{Rina Ben-Shahar}

Written language normatively transmits the full graphic pattern of a word without deviating from the spelling rules of a particular language. However, when graphic signs are intended to represent the spoken language used in natural conversation, the question of the phonetic imitation of spoken language in written texts arises. This is an important issue in the formation of dialogue style in narrative fiction, and even more so in drama, where the graphic mark-system is later transformed into one of auditory signs to be heard by an audience.

The present article deals mainly with the position of spoken language in Hebrew narrative fiction and drama and its modes of representation from 1948 until the late 80's, including both original Hebrew works and those translated from English into Hebrew. The corpus consists of more than 200 plays and short plays, 85 of which are translated works, as well as 90 novels and short stories, 45 of them are translated.

These questions are discussed in the context of several relevant broader issues: the linguistic-stylistic norms in Hebrew literature since 1948 and their transformations; Hebrew writers' and translators' awareness of the principles of spoken language in general, and those of the Hebrew vernacular in particular; the differences in dialogue formation between various literary sub-systems: drama as distinct from narrative fiction and original literature as distinct from translated 
literature, including some cross-sections of both. The large corpus used in the present article, and the long period during which the works under discussion were written, call for the study of the issues from both synchronic and diachronic points of view.

Between the end of the 1940's and the end of the 1980's some remarkable linguistic and stylistic changes took place in Hebrew narrative fiction and drama. The language of literature, which at the outset of that period drew mainly on the super-standard Hebrew of written sources, became more flexible. Both writers and translators began to make use of spoken Hebrew language options formerly ignored. Their language awareness seems to have gradually increased; from the 1940's up to the 1960's, whenever writers attempted to report speech in their writing, they wrote artificial dialogues in mixed language, mainly modelled on standard and super-standard written language norms, in which certain spoken Hebrew elements were embedded. During that period a large gap existed between Hebrew literary dialogue and spoken Hebrew conversation. From the 1960's on, literary dialogue has increasingly been growing to report authentic speech (Ben-Shahar, 1983, 1994a, 1994b).

This raises some questions. What is the position of the phonetic component of spoken language in Hebrew literary dialogues? Have writers and translators been paying attention to the phonetic components of speech, and, if so, which ways of imitating phonetic features of speech have been accepted by Hebrew literature (since the Establishment of the State), and which norms have crystallized for marking them in writing?

Generally speaking, the role played by the phonetic component in reporting speech in Hebrew literary dialogue has been quite minor compared with lexical, grammatical and syntactical-cohesive components or compared with the role played by the phonetic component in the dialogue language of other - such as the American and English - literatures. In this regard, differences may, of course, be found between various stages of the period under discussion, as well as various literary sub-systems: original as distinct from translated literature and drama as distinct from narrative fiction. Even today, when Hebrew writers and translators demonstrate a much higher awareness of 
spoken language, and the linguistic-stylistic model they use is infinitely richer and more flexible than before, they still do not tend to imitate spoken language phonetically, and resort to other linguistic means instead. Thus contemporary original Hebrew literature is almost completely devoid of phonetic characterization.

The scarcity of the phonetic component of spoken language in Hebrew literature dialogues may be attributed to the following factors:

1. A normative attitude towards Hebrew inherent in Israeli culture. This attitude deterred writers and translators (and still does) from deviating from the standard graphic form of words, whereas phonetic imitation of the spoken vernacular necessarily calls for deviation from the accepted spelling of words. Even though this stiff conservative attitude towards Hebrew has relented, language users still remain averse to such changes. Speakers' awareness of single word patterns in their language and of the way those are spelled is considerably higher than their awareness of other, less overt language characteristics, such as rhythmic-syntactic elements (Even-Zohar, 1985). Deviation from the rules of word usage and their accepted notation may therefore have a strong effect of violating broadly accepted norms.

2. Low awareness of the principles of spoken language in general, and those of spoken Hebrew, including its phonetic features, in particular, characteristic of the first half of the period under discussion (Ben-Shahar, 1983, 1994a, 1994b). This factor is closely linked to the previous one, since a conservative language community may well be expected to show greater respect and pay greater attention to written than to spoken language and relatively overlook the vocal aspect of language signs.

It would, however, be wrong to attribute low awareness of spoken language merely to language normativity. It also reflects the lack of procedures for simulating the vernacular in Hebrew literature (Even-Zohar, 1982, 1985). For, even when Hebrew writers of the 1950 's and 1960's deliberately used some elements of spoken Hebrew, they failed to perceive the various domains of the Hebrew language. Thus the modes of formulating spoken, or, rather, pseudo-spoken language in dialogues written during that period, mainly carried out by 
means of spoken Hebrew lexical elements, demonstrate a simplistic conception of language where lexemes determine the language level, and grammatical and syntactical-cohesive factors which organize them play but a secondary role (Ben-Shahar, 1983). Hebrew literature was late to develop linguistic-stylistic patterns of authentic speech. Even now, when the stylistic tools available to Hebrew writers and translators have been considerably refined, phonetic formation in literary dialogue is seldom put to use. This is a normative obstacle that has not been overcome, and perhaps never will.

3. The technical difficulty of marking phonetic imitation in Hebrew. In the Hebrew spelling system most vowels are not marked by letters. Vowel changes necessary in order to imitate phonetic phenomena of spoken language therefore call for the special use of an additional sign system, the pointing sign system. This purely technical complication may deter both writers and translators from using phonetic imitation, or make them repeatedly use a limited repertoire of phonetic elements.

\section{Variables affecting the language of a text}

In order to describe the phonetic representation of spoken language in several sub-systems of Hebrew literature, including original Hebrew drama, drama translated from English, original Hebrew narrative fiction and that translated from English, as well as the changes that took place in those during the period under discussion, several variables affecting the language of a text must be taken into consideration:

\section{Genre-specific characteristics}

a. Unlike narrative fiction texts, the text of a play is not considered as the "final product" of a given work. It is more like a musical score meant for vocal performance. On the one hand, the requirements of a live stage performance may make the playwright or translator of a play more likely to accept spoken language and more sensitive to its nuances. On the other hand the marginal position of the written text of the play may lead to a neglect of its written version.

b. Drama is a part of both the literary and theatrical systems. Thus its language is dictated not only by the linguistic and stylistic norms 
predominant in the contemporary literary system, but also by those predominant in the corresponding theatrical system. These two sets of norms need not necessarily agree with each other. Thus our findings reveal considerable language differences between plays actually performed, thus becoming part of the theatrical system, and others written to be read only. Whether a particular play was initially written for stage performance or for reading only is difficult to determine. However, whether a certain play was or was not performed and the identity of the playwright as one whose plays were or were not usually performed, are facts that have a clear bearing on the language of the play. The language of both original and translated plays perfomed on the stage was found to be closer to spoken Hebrew than that of plays which were not performed (Ben-Shahar, 1983).

2. The position occupied by the sub-system within the literary system as a whole

Norms affecting different literary sub-systems at a particular time are known not to work in parallel lines (sub-systems are classified according to such different criteria as genre; target audience, e.g. adult or childrens' literature; source or target literature. Translated literature may be further sub-classified into literatures of various nations, each of which occupies a different position within the literary system. (Even-Zohar, 1978, 1990b). Where drama is concerned, the position of a particular sub-system within the theatrical system, e.g. original as distinct from translated drama, further subdivided into the translated drama of different nations, must also be taken into account. Sub-systems that occupy a central position within the literary system often initiate innovations and dictate literary norms. Peripheral sub-systems usually stick to accepted models and seem to be immobile (Even-Zohar, 1978). This is demonstrated not only through various literary devices, but also through language use.

Thus, for example, original Hebrew literature written since 1948 has occupied a more central position than that of literature translated into Hebrew during the same period. This is expressed by language differences between these two sub-systems. During the 1940's original Hebrew literature already attempted to break through the stiff language model employed by writers until then, and to draw closer to 
spoken Hebrew (Ben-Shahar, 1983, 1994a). At the same time, translated literature still adhered to older norms formed by earlier literary traditions, almost completely ignoring spoken Hebrew. Hebrew writers and playwrights also active as translators thus usually employed as original writers considerably different norms from those they used as translators (Ben-Shahar, 1983).

Literatures pertaining to different nations also occupy different positions within the literary system (Even-Zohar, 1978, 1990b). The language used in drama translated from English, which has long occupied a central position within the Israeli theatrical system, especially since the late 1960 's, is greatly different from that used in drama translated from French, which has occupied a secondary position (Ben-Shahar, 1983). Narrative fiction translated from English has also occupied within the literary system a position more central than, that occupied by fiction translated from French, and the language model of the former has therefore been less limited and stiff than that of the latter.

\section{Original versus translated texts}

Original and translated texts differ in the extent to which they are open to the interference of a foreign language. The language of translated texts is necessarily influenced by the foreign language in which the original work was written and the specific language devices used in the original text (Toury, 1980, 1986; Weissbrod, 1989). A translated Hebrew dialogue is necessarily different from a contemporary original Hebrew dialogue, not only due to the different position of the original and translated literary sub-systems and their respective different linguistic and stylistic norms, but because the translated text has had direct contact with the original language. This difference is surely also noticable in the modes of phonetic formation.

A comprehensive examination of the language of a given text cannot be carried out without taking all the above-mentioned factors into account. 


\section{Modes of phonetic representation of spoken language}

A writer or playwright may display awareness of phonetic phenomena of spoken language in one of the following ways:

1. by introducing authentic phonetic phenomena of spoken Hebrew into dialogue language,

a. either according to the principles of spoken Hebrew performance (Toury, 1977);

b. or not according to the principles of spoken Hebrew performance.

2. by introducing phonetic phenomena ad hoc,

a. either as a direct transmission (phonetic calque) of phonetic phenomena in the original text in the case of a translated work;

b. or as sheer invention.

Phonetic formation may further be described in terms of its full or partial representation in the text. Phonetic imitation may be scant and arbitrarily used in a text, or recur repeatedly throughout the text. In between full and partial representation, there are of course several other degrees of presence.

The phonetic representation of spoken language in original Hebrew narrative fiction and drama

The 1940's witnessed a new tendency in Hebrew literature: the depiction of the Israeli-born figure against his natural background, using his own characteristic language. However, due to the lack of a tradition for simulating authentic speech in Hebrew literature, as well as their own low awareness of various domains of language and of the principles of speech, Hebrew writers and playwrights created a mixed dialogue language. This language combined different language levels and demonstrated a discrepancy between marked elements of sub-standard spoken Hebrew on the one hand and super-standard written language on the other (Ben-Shahar, 1983, 1994a 1994b). Marked spoken Hebrew elements, deliberately introduced into dialogue, were mainly lexical elements pertaining to contemporary Israeli slang, considered at that time as representing the spoken vernacular, as well as a few deviations from the ordinary spelling of words, imitating several phonetic phenomena of spoken language (ibid). 
A distinction should be made here between the nature of the language used in literary works written between the 40's and 60's, mainly dominated by written language norms, and writers' and readers' concept of language. During that period it was considered sufficient to distribute spoken language elements selectively and inconsistently throughout the dialogue for language to look like spoken language, violating standard language norms.

Until the 1960's, original drama was still an undeveloped genre of Israeli literature and theatre (Shaked, 1960; Ofrat, 1975), a phenomenon partially compensated by the use of translations, especially from English. Those few original plays written and performed in the Israeli theatre were mostly written by prominent contemporary writers and were partly adaptations of short stories or novels written by them. Original drama of that period, which was but a secondary sub-system, initiated no language innovation and, despite its particular needs, may be seen at that time as a mere satellite of original Hebrew narrative fiction.

Phonetic imitation of spoken language in original Hebrew fiction and drama of the 1950's and 1960's was usually partly and arbitrarily done, using a very limited language repertoire. It is hard to find an original Hebrew novel, short story or play where phonetic markers are consistently distributed in the language of a single character. Certain plays, short stories or novels use only a single or a few occurrences of a word or phrase imitating speech pronunciation, while no phonetic imitation is to be found in similar phonetic conditions in other parts of the text and in the speech of similar characters in similar situations. In the original drama of that period phonetic imitation is carelessly carried out; indeed, it is hard to speak of actual phonetic imitation, as phonetic phenomena look quite arbitrary.

The few phonetic phenomena in both original narrative fiction and drama of the 1950's and 1960's usually draw on authentic phenomena of spoken Hebrew, e.g. dropping weak consonants, such as a, h and sometimes ', and nullification of several vowels. Consonants, and sometimes also their accompanying vowels, are sometimes dropped in the middle of words and phrases, as in actual speech (mode la). However, writers often drop the weak consonants at the beginning of a 
sentence, where they are normally not dropped in actual speech (mode $1 \mathrm{~b}$; see examples below).

The Hebrew personal pronouns "ani" (I) and "ata" (you, mas. sing.) may be used in texts with the initial vowel dropped: "ani" > "ni"; "ata" > "ta." This phonetic abbreviation normally used in Hebrew speech in the middle of phrases and sentences, or at the beginning of a sentence with no pause between it and the preceding sentence, is usually represented in literary dialogues of Hebrew novels and plays of that period at the beginning of a sentence (mode $1 b$ ), where the initial syllable is normally retained in speech (see examples below). This reflects writers' low awareness of the principles of spoken language, as well as the more general common phenomenon of the more intensive distribution of various language markers at the beginning of utterances, where the writer's concentration and self-awareness are naturally greater, gradually decreasing as he writes on.

The scant and arbitrary representation of authentic phonetic phenomena in Hebrew literary dialogues is expressed, not only by the limited repertoire of phonetic phenomena of spoken language chosen for representation, but also in their application to a fixed stock of words and phrases, in which certain phonetic abbreviations tend to occur. Phonetic abbreviations mostly occur in personal pronouns and demonstratives.

Phonetic notation used by Hebrew literature to mark phonetic features of speech is usually made by dropping those letters that represent the weak consonants and dropping certain letters, representing vowels in Hebrew, in order to mark vowel nullization. An apostrophe mark, probably influenced by English usage, is used where letters have been dropped . Hyphens are sometimes used, and in other cases both apostrophes and hyphens are combined. The use of the pointing sign system to mark phonetic phenomena is not common, but may sometimes be found, especially in the works of S. Yizhar who, more than other writers of his time, tends to use phonetic imitation of actual speech and a greater variety of phonetic means.

Inconsistency in the modes of marking phonetic phenomena in dialogue language reveals, amongst other things, the lack of a tradition 
of phonetic representation of speech in Hebrew literature. Phonetic imitation was used in original Hebrew fiction for a very short time. In the 1960's most writers had stopped imitating phonetic phenomena of spoken language in their dialogues and formulated spoken language through other, increasingly varied means. As Hebrew writers' awareness of language in general and Hebrew in particular grew, they tended to give up over-marked language elements in both narrative and dialogue. They preferred to write their dialogues using neutral spoken language that did not immediately stand out as such. As stated above, a language user's attention is particularly drawn to single words of his own language and to their spelling. It was but natural that Hebrew writers of the 1940's and 1950's, who considered themselves as introducing considerable changes into the language of literature, should have violated the standards of Hebrew written language, especially for those language elements that draw the greatest attention, (using, as stated, lexical elements pertaining to the slang of their time, as well as a few phonetic phenomena of spoken language). When they had had some experience of reporting speech, as drawing on spoken language became more natural for them, the use of marked language elements became an obstacle, decreasing language authenticity. Deviation from written language standards in the notation of certain words for the purpose of phonetic imitation may draw exaggerated attention, beyond the relative part played by the phonetic elements in the dialogue (Ben-Shahar, 1994b).

The problematic use of spoken language in the young Israeli literature of the 40's and 50's and the changes in the attitude of Israeli writers to modes of its formation were discussed by the Israeli writer Moshe Shamir in a 1957 seminar organized by the cultural committee of the Tel-Aviv Workers' Council (for a written version, see Shamir, 1960). According to Shamir, the main contribution of young Israeli literature was made in the realm of language, using living spoken language for the first time in Hebrew literature. The language of those young writers, to quote Shamir, was first "chaotic inaccurate language that was indistinctly influenced by different sources." "If we first exaggerated in using spoken language, if we soon did our best to break free of it, it was merely a question of quantity. We first overused contemporary Hebrew slang, and then, when refraining from using it, we did not attempt to reject its vitality, but wished to reduce its use 
within a new combination where other language layers would also find as right a representation as possible" (ibid., p. 68) [emphasis original; translation is my own].

Shamir goes on to speak of the process of this change:

It is a process of giving up, much more than it is one of enrichment. Extreme cases of all kinds disappear. The writer gradually approaches the real core. Let me tell from my personal experience: side by side with the abundant slang I used in my earliest short stories and first novel, I also decorated my writing with Aramaic elements and literary cliche's, sometimes playing with language out of sheer expressionism. Just as slang was later dropped, so were those. The disappearance of "an'loy'de'a" (I dunno) or "kumzits" (colloquial word for adult social bonfire) slang forms was followed by the dropping of " $m$ 'eidax gisa" (on the other hand) and "mehaxa lehatam"' (by and by), the remnants of the Aramaic-Talmudic high style that used to be so popular for certain Israeli essay writers. (Ibid., pp. 69-70)

Unlike its fiction counterpart, original Israeli Hebrew drama of the 1970's and 1980's has not given up phonetic imitation of spoken language, and yet no considerable changes have been introduced into phonetic imitation modes since the 50's and 60's. During the 1970's original drama had already become a more advanced and independent genre. The theatre witnessed the growth of a new generation of playwrights, some of whom are also directors or actors, highly sensitive to spoken language, and yet but few of them pay considerable attention to its phonetic aspect. It should, however, be noted that a written text of a play, arbitrarily strewn with partial phonetic imitation, merely serves as the actors' "musical score," carrying a potential of full and consistent phonetic imitation of spoken language much more than actually marked.

Phonetic formation of dialogue language in narrative fiction and drama translated from English into Hebrew

\section{Narrative Fiction}

During the 1950's and 1960's narrative fiction translated from English into Hebrew was dominated by the norms of the super-standard written 
language. Translated literature was an epigonic sub-system that initiated no innovations, and acted according to the principles of the linguistic-stylistic model already crystallized within the Hebrew literary tradition. Within this model there was no room for spoken Israeli Hebrew, not to mention its phonetic phenomena. The language of translations into Hebrew was, to a great extent, artificial. It was heavily loaded, learned, abounding with collocations borrowed from ancient written sources and rare words, as well as invented elements, namely neologisms patterned according to written literary models. Compared with this language repertoire, the language of original Hebrew narrative fiction of that period was closer to a depiction of real life and more open to the Israeli language reality, and ready to cope with it.

Although translated fiction of the 1970's and 1980's has somewhat outstripped the old linguistic-stylistic model, it still employs a relatively conservative language, and its dialogues are still often written in the mixed language described above. Translators' exposure to source-text language, which often includes phonetic imitation of spoken dialects, sometimes makes them use phonetic imitation means. However, this is done quite arbitrarily. The position of the few occurrences of phonetic imitation included in the translated text usually depends on the position of phonetic phenomena within the source text and these are certainly not distributed throughout the translated text in cosideration of spoken Hebrew phonetic principles. This demonstrates, not only the low awareness of Hebrew translators of that time of spoken Hebrew principles, but also their tendency to provide a formal equivalence of the original text.

\section{Drama}

The language of drama translated from English into Hebrew during the 1950 's and 1960's mainly followed the linguistic-stylistic model that dictated the language of translated narrative fiction at that time. Thus the language of translated drama, too, "lagged behind" the language of original fiction and drama. However, unlike the language of translated fiction, where hardly any phonetic imitation of spoken language is to be found, translators of plays during the 1950's and 1960's occasionally did make some clumsy attempts at the phonetic formation of spoken language, in addition to selectively borrowing further elements from 
spoken Hebrew. The exposure of translators of plays to the language of English plays, where phonetic imitation was often used in order to form sub-standard dialects, must have been one of the reasons that made some translators of plays, at least, try to cope with the phonetic aspect of spoken language.

Another reason for the use of phonetic imitation in translated drama is, that during the entire period under discussion, plays were translated more as a part of theatrical activity than as part of literary activity (Ben-Shahar, 1983). Thus most of the plays translated from English into Hebrew were translated for stage performance. Such translations were therefore not published in book form or in literary magazines, but were copied for limited distribution as theatrical working texts. Translations were directly commissioned from the translators by the theatres, and there must have been some relationship between the translator and the theatre. The fact that drama translated from English into Hebrew pertained to the theatrical system may have encouraged translators to take the special needs of the vocal stage performance into some consideration. It should, however, be noted that most theatre translators of that period were also writers and poets, who also translated poetry and narrative fiction into Hebrew, and were thus considerably bound to written language norms, following the stiff stylistic model of literary translation into Hebrew.

Where phonetic imitation was made in plays translated during the 1950's and 1960's, phonetic markers were usually distributed throughout the text as single local phenomena, and the number of phonetic devices was as limited as it was in original Hebrew literature, though with a somewhat higher frequency.

A clear difference may be traced in the quality of phonetic devices used in the language of translated drama on the one hand and that of original narrative fiction and drama on the other. Thus drama translated into Hebrew abounds in invented phonetic devices, especially phonetic calques of phonetic phenomena figuring in the original text of the play (phonetic formation in the above mentioned modes $2 a$ and $2 b$ ). Where original fiction and drama use phonetic formation at all, they use authentic phonetic phenomena of spoken Hebrew (phonetic formation modes $1 \mathrm{a}$ and $\mathrm{lb}$ ). 
Translators into Hebrew thus tend to avoid using Israeli Hebrew, even at the cost of supplementing invented language elements. It should be noted that translated works of that period abound with various kinds of invented elements, including, besides phonetic elements, also lexical, grammatical and syntactic ones (Ben-Shahar, 1983, 1994b).

Up to the 1960's translators used to create "phonetic inventions," not only by means of calque. Where the original text included some sub-standard dialect elements, they often translated them by ad hoc arbitrary combinations of various language violations that do not reflect real spoken Hebrew pronunciation (mode $2 b$ ). Thus they arbitrarily dropped consonants and vowels or replaced them by others. This was sometimes combined with other modes, such as calque translation and occasionally borrowing authentic spoken Hebrew elements. Inventions of this sort reflect the conception, formerly widely accepted in Hebrew culture, and not yet completely given up, that all spoken language is vulgar.

During the 1960 's, and, especially during the 1970 's, the use of spoken language in plays translated from English into Hebrew increasingly grew. The gap between the language of these plays and that of original drama and narrative fiction regarding spoken language formation was gradually closed. Drama translated from English, by now occupying a central position in the Israeli theatre, disposed with epigonic literary norms. Translators for the theatre were no longer the established writers of the former generation; they were now new professional translators, highly aware of spoken language.

However, no substantial change took place in the phonetic mode of representing spoken language. Phonetic imitation remained a neglected phenomenon in Hebrew translated drama. Translators usually avoided source text phonetic imitation of spoken language, compensating for it by other language means. But unlike in plays translated during the 1950's and 1960's, phonetic imitations in plays translated during the 1970's and 1980's usually draw on authentic spoken Hebrew phenomena (phonetic representation is carried out by the above mentioned modes $1 \mathrm{a}$ and $\mathrm{lb}$, as it does in original Hebrew plays). A few translators attempt to phonetically imitate spoken 
language, consistently using full phonetic representation by varied means throughout the play. This mode of phonetic representation is missing in all other sub-systems discussed here, including original Hebrew drama, original Hebrew narrative fiction and drama translated during the 1950's and 1960's.

\section{Summary diagram}

The following diagram represents the distribution of phonetic representation within the various sub-systems discussed above during two periods: 1950's - 1960's and 1970's - 1980's.

$\mathrm{A}+$ mark indicates the scant existence of phonetic formation; $\mathrm{a}++$ mark indicates a relatively higher distribution, though scant.

\begin{tabular}{||l|c|c|c|c||}
\hline & $\begin{array}{l}\text { Original } \\
\text { fiction }\end{array}$ & $\begin{array}{l}\text { Original } \\
\text { drama }\end{array}$ & $\begin{array}{l}\text { Translated } \\
\text { fiction }\end{array}$ & $\begin{array}{l}\text { Translated } \\
\text { drama }\end{array}$ \\
\hline $\begin{array}{l}\text { The 50's } \\
\text { and 60's }\end{array}$ & + & - & - & + \\
\hline $\begin{array}{l}\text { The 70's } \\
\text { and 80's }\end{array}$ & - & + & + & ++ \\
\hline
\end{tabular}

This diagram clearly demonstrates that linguistic-stylistic norms operating within a certain sub-system during a given time do not necessarily correspond to those operating within another sub-system of the same period, as well as that a linguistic-stylistic situation inherent during a certain period in a particular sub-system may later exist within a different one.

\section{Examples and comments}

Following are examples from dialogues translated into Hebrew, both from fiction and from drama, demonstrating the different modes of phonetic representation described above. The examples exhibit these characteristics (or part of them): 
- A limited repertoire of phonetic-graphic means (omission of some consonants and/or vowels; avoiding consonant and vowel change), whereas source texts use a much richer variety.

. Scant and arbitrary distribution of phonetic imitation occurrences.

. Confining phonetic phenomena to a fixed stock of words or phrases (see examples 1-7, 11-12).

. Discrepancy between phonetic occurrences (marked as sub-standard elements) and super-standard elements in the same dialogue exchange (see examples 3 and 4).

. The position of phonetic phenomena in translated utterances depends considerably on the position of phonetic phenomena in the source utterances.

Introducing authentic phonetic phenomena of spoken Hebrew (modes 1a, 1b)

1. Look at 'em, sorr. The bloomin' dirty images! stakel bahem, adoni. partsufim mezohamim, yimax šmam! (J. Conrad, 1962, p.71, tr. S. Sandbank, 1961, p. 51)

[Hebrew transliteration; phonetic deviations are in italics; super-standard phrases are in bold letters.]

The standard Hebrew verb translating the verb "look" is "histakel," "histakli" (imperative masc. sing., imperative fem. sing). The initial weak consonant $h$ and its accompanying vowel were omitted. This contracted verb form (in different inflections of gender and number) is frequently used in the Hebrew vernacular, regardless of its position in the utterance (as initial or middle word). It seems that Hebrew translators are particularly aware of the phonetic contraction of this specific verb form in spoken Hebrew. Here is a similar example:

2. Looka here, I ain't got any dough for supper. 'stakli, motek, en li mezuman learuxat erev. (N. West, 1962, p. 111, tr. A. Krishak, 1980, p. 82)

3. Blamme if you don't look a blamed sight worse yikaxeni ofel im 'ta lo nir'e garua kiflayim than a broken down fireman. 
mi-kabai ratsuts.

(J. Conrad, 1962, p. 29, tr. S. Sandbank, 1961, p. 16)

In this example the Hebrew pronoun (masc. sing.) "ata" is contracted to "ta" in the middle of the utterance, as is usually the case in spoken Hebrew pronunciation.

In the source text from which examples 1 and 3 are taken dialogue is characterisedby an intensive phonetic imitation of a spoken dialect. The translator inserts a few occurrences of phonetic imitation, mainly in the first and second person singular pronouns, side by side with super-standard elements, such as the literary Hebrew exclamation "yikaxeni ofel" (example 3). This brings about a mixed artificial language, which does not conjure up the vernacular.

4. I'm awful [...] I'm diff'runt. I don't know why ani ayom $[\ldots]$ ani šone. eneni yodea madua

I make faux pas. 'Cause I don't care, ani tamid loke be-nimusai. ze mipnei se-lo'xpat $l i$, I s'pose. ani mešaer.

(S. Fitzgerald, 1960, p. 21, tr. T. Ornan, 1977, p. 17)

The single phonetic deviation in this utterance - "lo'xpat li" (I don't care) - is embedded in an elevated stylistic context (as is the case with other phonetic deviations in this translation). This Hebrew phrase (inflected in different persons) is one of the stock phrases, which figures in Hebrew translation as a contracted structure imitating spoken pronunciation, as is the contracted phrase "maz'tomeret" (standard phrase: "ma zot 'omeret" - what do you mean?/What does it mean?) appearing in the following example:

5. - You're such a funny boy. ata kol kax matsxik.

- How d'y mean?

m'z'tomeret?

(Ibid., p. 23, tr. p. 19)

6. I don't wanna be ratty. 
an'lo rotsa lihyot nivzit.

(J. D. Salinger, 1953, p. 59, tr. J. Dorf, 1979, p. 60)

The final vowel of the Hebrew pronoun "ani" (I) is omitted, and the contracted word is combined with the following negation word "lo" (not), to represent an authentic Hebrew phonetic phenomenon.

7. Just some goddam toilet paper, [...] Stopsa bleeding. rak eize neyar twalet mexurban, ze mafsik $t a^{\prime} d a m$. (Ibid., p. 64, tr. p. 62)

The Hebrew preposition "et" and the definite article "ha" form a contracted structure in spoken Hebrew: "et ha"> "ta," which adheres to the following noun. Although it is a very common usage, translators use it rarely and arbitrarily.

8. I declare yo'mammy one of de finest lady ani matshira še-imšlax hi axat ha-mal'axot haxi hagunot I know.

še-ani makira.

(M. Connely, 1963, p. 195, tr. D. Ben-Amotz, the late 50's, p. 6)

The contracted phrase "imslax" is a combination of two different words in standard Hebrew: "ima" (mommy), the final vowel of which is omitted in the translated dialogue, following spoken pronunciation, and "šelax" (your[s], fem. sing.).

It should be noted that the few occurrences of phonetic imitation in the translated texts parallel phonetic phenomena in the source texts as a result of the Hebrew translators' tendency to produce formal equivalence.

9. What I ought to've said was I'd just come down ma še-hayiti tsarix la'gid ze še-rak yaradti to say hallo.

lehagid šalom.

(J. Saunders, 1968, p. 16, tr. D. Alexander, 1970, p. 5) 
The inconsistent use of linguistic markers in Hebrew translations is demonstrated in this example, where, in the same sentence, the infinitive "lehagid" (translating the English infinitive "to say") is represented in the first occurrence by its contracted sub-standard form - "lagid," whereas in the second occurrence - by its standard form. This typical example exhibits, among other things, the Hebrew translators' tendency to treat each word or phrase in the source text as a separate entity, without being sufficiently aware of its interrelations with other entities in the same utterance or in other utterances in the text.

In the following three examples (10-12) translators drop weak consonants and their accomanying vowels in the beginning of utterances, where they are not dropped in actual Hebrew speech (translation in mode $1 \mathrm{~b}$ ). This is usually done under the influence of parallel source text deviated forms. Therefore such translated elements may be seen as lying on the border of calqus of the source text elements.

10. Orf yer go, me gel.

'xutsa at holexet na'arati.

(E. O'Neill, 1923, p. 59, tr. Y. Ramgal, 1959, p. 35)

The initial syllable ha was omitted from the word "haxutsa" (off, out), while the words "at holexet" are represented by their full standard forms, although the initial weak syllable of "holexet" in the middle of an utterance is usually ommitted in spoken Hebrew. Side by side with the phonetic deviation the translator uses a literary address term: "na'arati."

11. I ain't speakin' on'y fur meself.

'ni lo medaber rak bišvili.

(Ibid., p. 58, tr., ibid.)

12. Ya want me to hurry Selena up or anything?

'trotsa se-ani agid le-salena le-hizdarez o mašehu?

In example 11 the personal pronoun "ani" is contracted to "ni"; in example 12 the personal pronoun "at" is contracted to " $t$ " and is combined with the next word of the sentence. The influence of the 
phonetic phenomena position in the source utterances on their position in the target utterances can easily be traced.

13. 'The world is certainly a small place,' she said.

'ha'olam hu be'met makom katan', amra.

'What makes you say that?'

'biglal ma at omeret et ze?'

'I mean sudden,' said Frankie. 'The world is

'ani mitkavenet pit'omi', amra Frankie. 'ha'olam hu certainly a sudden place'.

be'met makom pit'omi'.

(C. McCullers, 1962, p. 10, tr. M. Yachil-Vax, 1984, p. 9)

Example 13 is a rare translational case where a Hebrew translator introduces a phonetic deviation into the dialogue, whereas the source dialogue does not contain phonetic markers. Compensation for certain linguistic means of the source text by different means in the target text is of course legitimate, but surprisingly enough, the Hebrew translator of this work confines the phonetic imitation of spoken conversation to three occurrences of a single word ("be-'emet"> "bemet" [certainly]) throughout the whole translation (the third occurrence of this contracted form appears in page 84 of the Hebrew translation).

Phonetic calques (mode $2 a)$

Invented phonetic means which are actually calques of the source text means are created by the phonetic phenomenon itself as well as by its graphic registration in the written text (Ben-Shahar, 1994b). It should be noted that the borderline between phonetic calques of the source text (mode 2a) and other modes of phonetic deviations (modes la and $1 \mathrm{~b}-$ introducing authentic phenomena, and mode $2 b$ - introducing intra-Hebrew inventions) is not distinct. Translators often tend to provide formal equivalents, that is, to stick very closely to the original language structure introducing a similar amount of linguistic elements and distributing them within the translated dialogue in manner similar to that found in the original text (ibid.). When translators imitate omission of consonants and vowels of the source text and use this 
device in words and phrases parallel to the contracted elements of the source text, this technique may be seen as a combination of calques with one of the other modes mentioned above.

14. I bet he'd back you. 'Cause he thought

ani batuax še-hu ya'azor lexa. 'pne še-hu xasav highly of you, Biff. alexa gdolot, Biff.

(A. Miller, 1969, p. 20, tr. T. Atar, 1967, p. 11)

The Hebrew causative "mipne še-" translating the authentic English contracted causative" 'cause" [because] is an invented element imitating the omission of the first syllable of the source word. Such form does not exist in any variety of Hebrew.

15. - May I leave my drink here? ani yaxol lehaš'ir kan et ha-kos?

- Yeah...sure...why not? kee, betax še-ken.

(E. Albee, 1965, p. 61, tr. T. Atar, 1965, p. 43)

In this example, as well as elsewhere in the play, the Hebrew translator introduces into her text a pseudo-spoken element, as a phonetic calque of a particular pronunciation of the English word "yeah": she drops the final consonant of the Hebrew word "ken"' (yes) and marks the lengthening of the final vowel by duplicating the Hebrew vowel letter:"ken"> "kee." This pronunciation of "ken," however, does not exist in Hebrew, so that the introduction of a familiar element in a new kind of spelling seems strange, even impossible to understand.

16. Yessam.

ken gve't.

(E. Bond, 1975, p. 13, tr. A. Ben-Nachum, the late 60's, p. 13)

The English source text uses the phonetic abbreviation of the phrase "Yes, Madam." Just as the middle syllable of the English word "madam" was dropped, so too was the middle syllable of the parallel Hebrew word: "gveret"> "gve't." This, too, is an invented abbreviation not based on any authentic phonetic phenomenon in spoken Hebrew. 
Surprisingly enough, the translator chose to ignore the authentic phonetic vatiety of "giveret," already available in the vernacular at that time (compare to example 22 below).

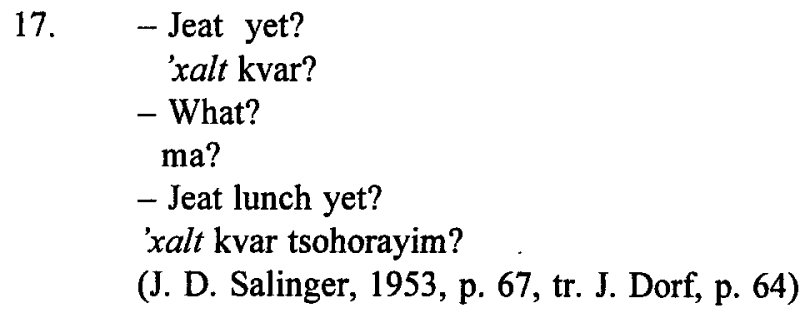

In the source text, phonetic abbreviation and phonetic deviation are used at the beginning of the phrase. By way of imitation the translator has dropped the entire first syllable of the Hebrew phrase, constituting the first syllable of the verb form ("axalt"> "xalt") even though syllables in this position are never dropped in Hebrew speech.

\section{Introducing intra-Hebrew inventions (mode $2 b$ )}

18. Theres menners f yer! $T$-oo banches o voylets eizo min tna'agu క̌e-kazoti! šalos xavilot sgulio trod into the mad.

tox ha-bots.

(G. B. Shaw, 1966, p. 15, tr. Y. Ratosh, 1954, p. 5)

19. Cheer up, Keptin; n'baw ya flahr orf a pore gel! az al tihye atsuv, kapitan; 'ukne pexax mi-bax' $x a$ aniya. (Ibid., p. 21, tr. p. 9)

The Hebrew translator creates a pseudo-spoken dialect by introducing a varaiety of deviated artificial forms. He drops indiscriminately different letters, even those representing strong consonants, which are never dropped in Hebrew speech, e.g. "sguliot" (violets)> "sgulio"; "hitnahagut" (behaviour, manners)> "tna'agu" (example 18); "baxura" (girl)> "bax'xa." (The omission of a middle vowel and a consonant of this word is probably an imitation of the contracted source word "gel" [example 19].) He arbitrarily replaces letters (consonants) by others, e.g. "perax" (flower)> "pexax" (ibid). The translator does not look for 
existing phenomena of sub-standard Hebrew which may carry similar function to the sub-standard dialect phenomena of the source text, but rather invents elements of his own.

20.

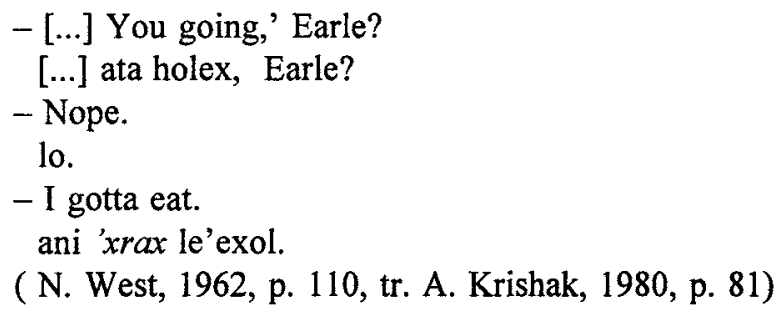

The dropping of the initial half syllable of the Hebrew word "muxrax">"'xrax" (must) is an invention. This invented element borders between intra-Hebrew invention (mode $2 b$ ) and calque of the elements in the source text (mode 2a).

\section{Full phonetic imitation}

Of all the Hebrew translators only one - Rivka Meshulah, who is a theatre translator, - produces a functional equivalence to the phonetic formation of English source texts. She imitates phonetic phenomena of spoken Hebrew with a rich variety of authentic elements which are distributed through the translated text fully and consistently, not depending on the form and the location of phonetic phenomena in the source text. In addition to the use of the apostrophe which is the accepted mark in Hebrew translations for recording phonetic contractions, she uses the Hebrew pointing sign system for representing vowel change typical of sub-standard Hebrew, as well as an unconventional mark, the slash, marked on letters representing consonants or vowels to be dropped in oral performance. The translator's idiosyncratic phonetic notation enables an easy decoding of the text, even when intensively representing sub-standard dialect, e.g.:

21. It'll be great! It'll be conspiracy man! chma, ze yihye 'atsum. chma - zot tihye maxteret. Well what d'y' think?

az ma ta 'omer?

(D. Halliwell, 1966, p. 15, tr. R. Meshulah, 1967, p. 8) 
Apart from omission of weak consonants (marked by a slash), the translator introduces into the dialogue authentic phonetic phenomena which, although common in the vernacular, are never used in other Hebrew translations, such as the contracted form of the verb "tišma" (listen, masc. sing.) as "tšma," the initial consonant of which (pronounced ch) is marked here by a "foreign" sign, confined in Hebrew to foreign words only.

22. Mornin', missus.

boker tov giveret.

(E. Bond, 1973, p. 31, tr. R. Meshulah, 1985, p. 42)

The word "gveret" (madam, missis) is represented here by its authentic spoken Hebrew pronunciation - "giveret" - and compare to example 16, where another translator, some 20 years earlier, introduced an invented pronunciation of the same element. The literary translations of the 80 's demonstrate a higher acceptance of spoken Hebrew as well as new linguistic stylistic norms that penetrated into the literary translation into Hebrew ${ }^{1}$.

\section{Conclusion}

The present article has attempted to demonstrate the part played by the phonetic component in the representation of Hebrew dialogue in narrative fiction and drama. How this component was dealt with by writers and translators indicates how Israeli literature and theatre coped with reporting speech. It also exemplifies the ways of representing language reality in literary works.

The problem of dialogue stylization was one of the main stylistic problems of Israeli narrative fiction and drama, perhaps the most important one of all. The great difficulty involved was not merely the result of the "poorness" of spoken Hebrew, as it is frequently claimed to be, but stemmed from a lack of tradition for reporting speech in Hebrew literature.

1. In view of technical constraints, particularly the inability to illustrate the Hebrew pointing sign system, no more examples of Meshulah's translations are quoted. 
Modes of phonetic imitation of spoken language in Israeli narrative fiction and drama dialogues clearly demonstrate that writers and playwrights do not directly borrow language material from the vernacular. Instead, cultural-linguistic norms mediate and dictate to the writer his selection and use of language materials out of this reality.

It took a few decades until Israeli narrative fiction and drama managed to absorb spoken Hebrew, to practise them in short stories, novels and plays and to adapt them into accepted literary dialogue patterns. Due to the above mentioned cultural and linguistic causes, Israeli narrative fiction and drama greatly abandoned the phonetic aspect of spoken language, preferring other language aspects. Against the background of accepted patterns of dialogue representation in contemporary Hebrew literature, especially original Hebrew literature, the phenomena of phonetic imitation of spoken language may seem eccentric and overmarked. Only time will tell whether phonetic imitation phenomena will be eventually absorbed into Israeli Hebrew narrative fiction and drama and become part and parcel of the accepted "natural" patterns of literary dialogue representation.

Rina Ben-Shahar, Department of Linguistics and Hebrew Language, University of Haifa, Oranim College Division, Kiryat Tivon, 36910 Israel.

E-Mail Address: zeac109@uvm.haifa.ac.il

\section{References}

BEN-SHAHAR, Rina (1983). Dialogue Style in the Hebrew Play, Both Original and Translated from English and French, 1948-1975, 1-2. Tel-Aviv University, Tel-Aviv [Ph.D. Thesis] (in Hebrew; English summary).

(1994a). "The Development of Dialogue Language in the Israeli Prose: The Main Stages," Sadan: Studies in Hebrew Literature, ed. D. Laor. Tel-Aviv University, pp. 217-240 (in Hebrew).

(1994b). "Translating Literary Dialogue: A Problem and Its Implications for Translation into Hebrew," Target, VI(2), pp. 195-221. 
EVEN-ZOHAR, Itamar (1978). "The Relations between Primary and Secondary Systems in the Literary Polysystem," Papers in Historical Poetics. The Porter Institute for Poetics and Semiotics, Tel-Aviv University, Tel-Aviv, pp. 14-21.

(1982). "The Emergence of Speech Organizers in a Renovated Language: The Case of Hebrew Void Pragmatic Connectives," Impromptu Speech: A Symposium, ed. N. E. Enkvist. Abo Akademi, Abo, pp. 179-193.

(1985). "Gnessin's Dialogue and Its Russian Models," Slavica Hierosolymitana, 17, pp. 17-36. [A revised version in Even-Zohar (1990a), pp. 131-153.]

(1990a). Polysystem Studies. Durham, Duke University Press. Poetics Today, XI(1) (Spring).

(1990b). "The position of Translated Literature within the Literary Polysystem," in Even-Zohar (1990a), pp. 45-51.

OFRAT, Gideon (1975). IsraeliDrama. Cherikover and the Hebrew University of Jerusalem, Jerusalem (in Hebrew).

SHAKED, Gershon (1960). "Some Aspects of Original Israeli Drama," Bamah (Drama Quarterly), 6 (July), pp. 9-17 (in Hebrew).

SHAMIR, Moshe (1960). With a Swift Pen. Sifriyat Poalim, Merhavia, pp. 59-71 (in Hebrew).

TOURY, Gideon (1977). Translational Norms and Literary Translation into Hebrew, 1930-1945. The Porter Institute for Poetics and Semiotics, Tel-Aviv University, Tel-Aviv (in Hebrew).

(1980). In Search of a Theory of Translation. The Porter Institute for Poetics and Semiotics, Tel-Aviv University, Tel-Aviv.

(1986). "Monitoring Discourse Transfer: A Test-Case for a Developmental Model of Translation," in House, Juliane and Shoshana Blum-Kulka, eds. Interlingualand InterculturalCommunication: Discourseand Cognition in Translationand Second Language AcquisitionStudies, Gunter Narr Verlag, pp. 79-94.

WEISSBROD, Rachel (1989). Trends in Translation of Prose Fiction from English into Hebrew, 1958-1980. Tel-Aviv University, Tel-Aviv [Ph.D. Thesis] (in Hebrew; English summary). 
Literary works quoted in the article (original and Hebrew translations)

ALBEE, Edward (1965). Who's Afraid of Virginia Woolf? New York, Pocket Books.

[1965]. Mi mefaxed mi-Virginia Woolf? tr. Titza Atar. Ha-merkaz le-tarbut u-le-xinux sel ha-histadrut, [Tel- Aviv].

BOND, Edward (1975). Lear. Eyre Methuen, London. Bond, Edward the late 60's] Lear, tr. Ada Ben-Nachum. Beit Tsvi, Ramat Gan, 1980.

(1973). The Sea. London, Eyre Methuen.

BOND, Edward (1985). Ha-yam, tr. Rivka Meshulah. Beit Tsvi, Ramat Gan.

CONNELY, Marc [the late 50's] Ne'ot dese, tr. Dan Ben-Amotz (stencil).

(1963). "Green Pastures," Twenty Best Plays of the Modern American Theatre, 1st series, ed. J.C. Gaskin.

CONRAD, Joseph (1962). The Nigger of the Narcissus. New York, Collier Books.

(1961). "Ha-kusi 'is narkis," Re'i ha-yam, tr. Shimon Sandbank. Sifriyat poalim, Merhavia.

FITZGERALD, Scott (1960). "This Side of Paradise," Scott Fitzgerald, v. 3. The Bodly Head, London.

(1977). Bo'axa gan eden, tr. Tuvia Ornan. Cherikover, Tel-Aviv.

HALLIWELL, David (1966). Little Malcolm and his Struggle against the Eunuchs. London, Faber and Faber.

Meshulah (stencil).

(1967). Malcolm ha-katan u-milxamto ba-sarisim, tr. Rivka

MCCULLERS, Carson (1962). The Member of the Wedding. Middlesex, Penguin Books.

(1984). Xaverutba-xatuna, tr. Miriam Yachil-Vax. Keter, Tel Aviv.

MILLER, Arthur (1969). Death of a Salesman. Middlesex, Penguin Books. 
(1967). Moto sel soxen, tr. Tirza Atar. Ha-merkaz le-tatbut u-le-xinux sel ha-histadrut, [Tel-Aviv].

O'NEILL, Eugene (1923). "The Long Voyage Home," The Moon of the Caribees and Six Other Plays of the Sea. New York, The Modern Library.

(1959). Ha-masa ha-'arox ha-baita, tr. Yanez Ramgal. Ha-yamai ha-yisre'eli, 47 (February), pp. 34-40.

SALINGER, J. D. (1953). "Just berore the War with the Eskimos," Nine Stories. New York, The Modern Library.

(1979). "Mamas lifnei ha-milxama im ha-eskimosim," tr. J. Dorf. Tis'a sipurim. Siman kri'a, Tel-Aviv.

SAUNDERS, James (1968). "Neighbours," Neighbours and Other Plays. London, André Deutsch.

[1970]. Sxenim, tr. David Alexander (stencil).

SHAW, George Bernard (1966). Pygmalion. Middlesex, Penguin Books.

[1954]. Pygmalion, tr. Yonatan Ratosh. Ha-merkaz le-tarbut u-le-xinux sel ha-histadrut, [Tel-Aviv].

WEST, Nathanael (1962). "The Day of the Locust," Miss Lonelyheartsand the Day of the Locust. New York, New Directions.

Tel-Aviv.

(1980). Yom ha-'arbe, tr. Arie Krishak. Zmora, Bitan, Modan,

ABSTRACT: The Phonetic Representation of Spoken Language in Modern Hebrew Literature - Written language normatively transmits the full graphic pattern of a word without deviating from the spelling rules of a particular language. However, when graphic signs are intended to represent the spoken language used in natural conversation, the question of the phonetic imitation of spoken language in written texts arises. The present article deals with the position of spoken language in Hebrew narrative fiction and drama, and the modes of its representation from 1948 on, including both original Hebrew works and those translated from English into Hebrew. This issue is discussed against the background of such relevant broader issues as: the special situation of Hebrew, which had long been used as a written language only, devoid of the 
varied functions of spoken language; linguistic-stylistic norms in Hebrew literature from 1948 on and the changes they underwent; Hebrew writers' and translators' awareness of the principles of spoken language in general, and those of the Hebrew vernacular in particular; differences in dialogue formation between various literary sub-systems: drama as distinct from narrative fiction and original literature as distinct from translated literature, including some cross-sections of both. The issues are discussed from both the synchronic and diachronic points of view.

RÉSUMÉ: La représentation phonétique de la langue parlée dans la littérature hébraïque moderne-La langue écrite transmet de façon normative le modèle graphique complet d'un mot sans dévier des règles orthographiques d'une langue donnée. Cependant, lorsque les signes graphiques visent à représenter la langue parlée utilisée dans une conversation naturelle, le problème de l'imitationphonétique de la langue parlée retranscrite dans un texte se pose. Le présent article traite de la position de la langue parlée dans les fictions narratives et dans le théatre en hébreu, ainsi que ses modes de représentation à partir de 1948 dans des œuvres en hébreu, y compris des œuvres traduites de l'anglais. Cette question est abordée en faisant fond sur d'autres questions plus vastes: la situation particulière de l'hébreu, qui a longtemps été exclusivement une langue écrite dénuée des fonctions variées d'une langue parlée; les normes stylistiques-linguistiques de la littérature hébraïque depuis 1948 et leurs transformations; la conscience que les écrivains et les traducteurs hébreux avaient des principes de la langue parlée en général et de ceux du vernaculaire hébreu en particulier; les différences dans la formation des dialogues entre les divers sous-systèmes littéraires: le thêâtre par rapport à la fiction narrative et la littérature en langue d'origine par rapport à la littérature traduite, y compris les intersections des deux. Ces questions sont abordées sous un angle tant synchronique que diachronique. 